$\xi=-1$

\title{
Construction of Optimal Portfolio and Selection of Stock using Fuzzy Approach
}

\author{
Ity Patni ${ }^{1 *}$, Nishu Gupta ${ }^{1}$ \\ ${ }^{1}$ School of Business \& Commerce, Department of Business Administration, Manipal University Jaipur (Rajasthan), India \\ *Corresponding author E-mail: ity.patni@ jaipur.manipal.edu
}

\begin{abstract}
Stock selection methods and strategies have been the prominent area of research since long. Portfolio theory is a connotation how an intelligent bias free investor should make an optimal portfolio. The line of the work is first inclined towards construction of optimal portfolio using Sharpe-Single Index model, CAPM, Jenson's Measure, Treynor \& Sharpe Ratio. These measures consider total risk i.e. systematic and unsystematic risk and suggests a rational investor in what proportion an investment can be made to a particular stock. Further, the purpose of the work is to combine the fuzzy approach for closer representation with reference to stock selection problem in a nonlinear and uncertain environment. For demonstration, data set is taken from National Stock Exchange (NSE) for a period of 6 years (1st April, 2011 to 31st March, 2017). The proposed model will serve both ranking and assigning weight procedures to the selected stocks.
\end{abstract}

Keywords: Optimal Portfolio, Sharpe-Single Index Mode, CAPM, Jenson's Measure, Treynor's Ratio \& Sharpe Ratio

\section{Introduction}

While dealing with complex problems, one can hardly avoid uncertainty. Empirically, uncertainty is non-detachable part of almost any real world problem as decision making is in the hands of uncertain contemporary environment. At both cognitive and emotional level, it blooms from the vagueness and ambiguity.

The Stock Market is one of the key areas where uncertainty is at peak. The decision making is always complex under stock selection as varied cognitive and emotional biases work at the same time. Instrumentally, the investor has to see the ways for investment decisions backed by meticulous analysis no matter fundamental, technical or some other strategies ${ }^{121}$. The profounder of stock pricing theories have explored methods under traditional finance for evaluating any security and finally for construction of a portfolio. The CAPM was initiated by 2345 independently, structuring the past research piece of work of Harry Markowitz on diversification and modern portfolio theory ${ }^{6 .}$ Similarly, Markowitz Theory of Portfolio, Treynor's \& Jenson's Ratio and Sharpe Single Index Model etc. are the landmark theories which paves the way for investors to decide which security to buy and in what proportion in a portfolio construction.

This idea of writing this research paper primarily starts with the selection of stocks. Out of 50 Nifty securities, exclusion was performed based on Sharpe-Single Index model, CAPM, Jenson's Measure, Treynor \& Sharpe Ratio. This process of fundamental analysis resulted in 9 securities on which Fuzzy Logic was applied for giving ranking and assigning weight to each security for construction of a portfolio.

\section{Review of Related Literature}

There There are varied approaches to construct an optimal portfolio. Markowitz's seminal works $(1952,1959)$ provide the standard model to solve asset allocation problems. It is called MeanVariance Optimization or Mean-Variance Analysis and is generally regarded as the cornerstone of Modern Portfolio Theory ${ }^{7}$. ${ }^{8}$ CAPM brings a new point of view to the asset valuation. Sharpe's model is based on the idea of balance between risk $(\beta)$ and expected yield and loss of investment. This method allows the investor to make an optimal portfolio, which is consistent with the market. The single index model is backed by the theory that securities tandem are together because of the common wave in markets and there are no effects beyond the market that account the stocks co- movement. The expected return, standard deviation and covariance of the single index model represent the joint movement of securities. Treynor formulated the notion of the security market line, which expresses the relationship between returns of the portfolio and market whereby the slope of the line measures the relative volatility between the portfolio and the market (as represented by beta). The beta coefficient is simply the volatility measure of a stock portfolio to the market itself. The magnitude of slope represents the best risk-return trade off. Treynor measure is also known as the reward-to-volatility ratio ${ }^{9}$. Jensen's measure is also known as Jensen's alpha based on the theory ${ }^{10}$, is a positive value on Jensen's measure which shows that the portfolio earned a return in excess of its risk and market adjusted required return. In Jensen's measure the zero value illustrates that the portfolio has earned the required rate, whereas a negative value connotes that it doesn't meet the required return expectations.

${ }^{11}$ dealt with the portfolio selection problem with three numerical problems over traditional approaches. ${ }^{12}$ proposed two types of portfolio selection approach, i.e. fuzzy probability and possibility distributions. Investor's expert knowledge was attempted for mod- 
elling. Portfolios are selected to minimize the variance of the returns based on fuzzy possibility and probability distribution. The return's spread was too fuzzified. ${ }^{13}$ proposed a model to determine portfolio through fuzzy attributes which signifies that if an investor is risk averse the variance should be small and a thrill seeking investor would anticipate higher risk and profitability targets and lower liquidity notions. Fuzzification helps investor to refine expectations.

\section{Objectives of the Study}

The purpose of the research is to construct the optimal portfolio, which comprises the stock of NSE using the risk adjusted approach: Sharpe, Jensen \& Treynor. Further, the fuzzy logic was applied for assigning weights and ranks to the selected stocks. This gives an impression to construct a portfolio with a proper weightage to relevant stock based on fundamentals.

\section{Research Methodology}

The type of this research is quantitative descriptive analysis. For the purpose of demonstration Nifty 50 companies were observed from 1st April, 2011 to 31st March, 2017. The criterion of selection of stock is based on certain methods. Each method may give varied output depending upon the risk adjustment approach propounded by different authors. Table 1.1 is representing the applied formula of each method and selected stocks based on the similar criterion. This is the first step to identify prominent stocks for portfolio construction. Further, the methodology would compare pair wise ranking in fuzzy logic to identify the prominent stocks and the proportion in which they would take place in a portfolio.

The output after applying methods for stock selection was limited to 9 prominent companies. Fuzzy logic was introduced by Lotfi Zadeh in 1965 which is a generalization of classical set theory 14 The fuzzy set theory has some intuitively appealing formalisms which appear suitable for modelling natural cognitive schema15. On 9 remaining stocks which were weighed strongly, the value investing notion was applied, which is more concerned with fundamentals of the company rather than stock prices or market factors. The value investing strategy was introduced by Benjamin Graham in 1920 in which author suggested 7 criterion for evaluating value stocks such as; credit rating of earnings \& dividend, total debt to current asset ratio, current ratio, earnings per share growth (EPSG), P/E Ratio, Price to book value ratio \& dividend pay-out ratio16. Supplementary to stock selection methods, on the basis of these 7 value investing criteria, 9 stocks were given weightage as per their fundamentals.

\subsection{Fuzzy Methodology}

In this section, fuzzy numbers have been used in which $\tilde{A}$ is signified as the triplet of real numbers $(1, \mathrm{~m}, \mathrm{u})$, where $1<\mathrm{m}<\mathrm{u}$. This signification of ' $m$ ' states the maximum bar of the membership function whereas ' $l$ ' and ' $u$ ' are respectively the lower and upper limits of the equation. For illustrating the triangular fuzzy numbers and for generating weights arithmetic expression can be observed as $\tilde{\mathrm{A}}=\left[\mathrm{A}_{\mathrm{l}}, \mathrm{A}_{\mathrm{m}}, \mathrm{A}_{\mathrm{u}}\right]$ and $\tilde{\mathrm{B}}=\left[\mathrm{B}_{\mathrm{l}}, \mathrm{B}_{\mathrm{m}}, \mathrm{B}_{\mathrm{u}}\right]$

For better understanding of generation of fuzzy numbers, few steps are followed:

Step I: For calculating weights, three conditions exist out of which first two conditions are to be satisfied and there is no need to follow the third condition for the same

a. $\quad A_{m} \geq B_{m}$

b. $\quad \mathrm{A}_{\mathrm{l}} \geq \mathrm{B}_{\mathrm{u}}$

c. $\left(\mathrm{A}_{\mathrm{m}}-\mathrm{B}_{\mathrm{u}}\right) /\left(\mathrm{B}_{\mathrm{m}}-\mathrm{B}_{\mathrm{u}}\right)-\left(\mathrm{A}_{\mathrm{m}}-\mathrm{A}_{\mathrm{l}}\right)$
Step II: The comparison of $\tilde{\mathrm{A}} \longrightarrow \tilde{\mathrm{B}}$. $\tilde{\mathrm{N}}$ is to be made and the minimum of the integral value is to be taken as final weight for the variables.

In the case of triangular fuzzy numbers with positive supports, the generic element of the n-dimensional fuzzy pairwise comparison matrix can be represented by $\mathrm{a}_{\mathrm{ij}}=\left(\mathrm{l}_{\mathrm{ij}}, \mathrm{m}_{\mathrm{ij}}, \mathrm{u}_{\mathrm{ij}}\right)$. To preserve the symmetry ${ }^{17}$, we need

$\mathrm{a}_{\mathrm{ji}}=\left(1 / \mathrm{u}_{\mathrm{ij}}, 1 / \mathrm{m}_{\mathrm{ij}}, 1 / \mathrm{l}_{\mathrm{ij}}\right), \forall \mathrm{i} \neq \mathrm{j}$

and

$\mathrm{a}_{\mathrm{ji}}=(1,1,1), \forall \mathrm{i}=\mathrm{j}$

The value of the fuzzy synthetic extent is defined, using the standard fuzzy arithmetic, as below:

$S_{i}^{k}=\sum_{j=1}^{n} M_{i j}^{k} X\left[\sum_{i=1}^{n} \sum_{j=1}^{n} M_{i j}^{k}\right]^{-1}$

where the signs $\Sigma$ and $\mathrm{x}$ signifies the summation and product operations in fuzzy mathematics, and $\mathrm{Mk}_{\mathrm{ij}}$ is a triangular fuzzy number which is representing the ratio between the stock $i$ and the stock $\mathrm{j}$ in comparison with the goal $\mathrm{k}$. In general, $\mathrm{Mk}_{\mathrm{ij}}$ is the nomenclature used in fuzzy pairwise comparison as being used in AHP (Analytical Hierarchy Process) ${ }^{19}{ }^{20}$. It is stating the performance of the $\mathrm{i}^{\text {th }}$ stock in comparison with the $\mathrm{k}^{\text {th }}$ element which is correspondent to fuzzy AHP ultimate score.

For the research piece of work, the secondary data was taken for the same demonstrated period from $1^{\text {st }}$ March, 2011 to $31^{\text {st }}$ March, 2017. Table 2 depicts the fuzzy triangular scale from 1 to 9 on which one company was pair wise compared with another company on the basis of 7 value investing criterion. The notion of rating scale constitutes verbal categories to rate opinion. This vague source is transformed in the form of fuzzy numbers ${ }^{18}$. This assumes the practice of fuzzy rating scale which deals with the result conversion of classical measurement done by rating scales in the form of fuzzy numbers.

Table 1: Stock Selection Methods \& Selected Stocks (NSE)

\begin{tabular}{|c|c|c|c|c|c|}
\hline & $\begin{array}{l}\text { Sharpe } \\
\text { Single } \\
\text { Index } \\
\text { Model }\end{array}$ & $\begin{array}{l}\text { Capital } \\
\text { Asset } \\
\text { Pricing } \\
\text { Model }\end{array}$ & $\begin{array}{l}\text { Jensen's } \\
\text { Measure }\end{array}$ & $\begin{array}{l}\text { Tre } \\
\text { yno } \\
\text { r's } \\
\text { Ra- } \\
\text { tio }\end{array}$ & $\begin{array}{l}\text { Sharpe } \\
\text { Ratio }\end{array}$ \\
\hline $\begin{array}{l}\text { For- } \\
\text { mula }\end{array}$ & $\begin{array}{l}\mathrm{R}(\mathrm{i})- \\
\mathrm{R}(\mathrm{f}) / \beta \\
\text { (i) }\end{array}$ & $\begin{array}{l}\mathrm{ra}= \\
\mathrm{rrf}+ \\
\mathrm{Ba}(\mathrm{rm}- \\
\mathrm{rrf}) \\
\text { Where, }\end{array}$ & $\begin{array}{l}\text { Alpha = R(i) - } \\
(\mathrm{R}(\mathrm{f})+\mathrm{B} \times(\mathrm{R}(\mathrm{m}) \\
\text { - R(f) } \\
\text { Where, }\end{array}$ & $\begin{array}{l}\text { (Ri } \\
\mathrm{Rf}) / \\
\mathrm{B} \\
\text { Wh } \\
\text { ere, }\end{array}$ & $\begin{array}{l}S(x)=(r x- \\
R f) / \\
\text { StdDev (x) }\end{array}$ \\
\hline $\begin{array}{l}\text { Se- } \\
\text { lected } \\
\text { Stock }\end{array}$ & $\begin{array}{l}\text { Hindal } \\
\text { co, Dr. } \\
\text { Reddy, } \\
\text { IOCL, } \\
\text { Bharti } \\
\text { Infratel }\end{array}$ & $\begin{array}{l}\text { Hindalc } \\
\text { o, Dr. } \\
\text { Reddy, } \\
\text { India } \\
\text { Bulls, } \\
\text { Adani, } \\
\text { IOCL, } \\
\text { Bharti } \\
\text { Infratel } \\
\text { Auro- } \\
\text { bindo } \\
\text { Pharma }\end{array}$ & $\begin{array}{l}\text { Eicher Motors, } \\
\text { India Bulls, Indu- } \\
\text { sind Bank }\end{array}$ & $\begin{array}{l}\text { Hin } \\
\text { dalc } \\
\text { o }\end{array}$ & $\begin{array}{l}\text { Eicher } \\
\text { Motors, } \\
\text { India Bulls }\end{array}$ \\
\hline
\end{tabular}

Table 2: Fuzzy Fundamental Scale (1-9)

\begin{tabular}{|l|l|l|}
\hline Fundamental Scale & Definition & $\begin{array}{l}\text { Fuzzy Triangular } \\
\text { Scale }\end{array}$ \\
\hline 1 & Equally Preferred & $(1,1,1)$ \\
\hline 3 & Weakly Preferred & $(1,3 / 2,2)$ \\
\hline 5 & $\begin{array}{l}\text { Fairly Strongly Pre- } \\
\text { ferred }\end{array}$ & $(3 / 2,2,5 / 2)$ \\
\hline 7 & $\begin{array}{l}\text { Very Strongly Pre- } \\
\text { ferred }\end{array}$ & $(2,5 / 2,3)$ \\
\hline 9 & Absolutely Preferred & $(5 / 2,3,7 / 2)$ \\
\hline $2,4,6,8$ & Intermediate Values \\
\hline
\end{tabular}


For testing and finding the value of consistency of stock performance with the 7 value criterion, a comparison matrix was made depended on $\mathrm{n}$ and the consistency rate (CR) has been computed $\mathrm{CR}$ is nothing but the ratio between consistency of a consistency index $(\mathrm{CI})$ and of random consistency index $(\mathrm{RCI})$. The value of RCI should not be greater than 0.1 for a matrix greater than $4 * 4$ The computation is done on the following basis:

$C R=C I / R C I$

The consistency index is relevant for measuring the inconsistency for pairs where the eigenvalues in each category can be computed by averaging them as a whole by following $C I=\left(\lambda_{\max -n}\right) /(n-1)$. Further, the evaluation of measuring the importance of a particular Value Criterion in selection of stock is computed with the help of $\lambda_{\max }=\sum_{j-1}^{\mathrm{n}} a_{i j} \frac{W_{j}}{W_{i}}=n, i, j=1,2, \ldots \ldots \ldots, n$

In Table 3, 9 stocks were evaluated on the basis of 7 value criterion proposed by Benjamin Graham for which secondary data was taken from stock's website, moneycontrol, yahoofinance, screener (Stock screener for Indian stocks). Following thresholds were observed:

- Value Criteria 1: Graham recommended stocks using better credit ratings

- Value Criteria 2: Buying companies with Total Debt to Current Asset ratios of less than 1.10.

- Value Criteria 3: Companies with Current Ratio over 1.50

- Value Criteria 4: Companies with positive earnings per share growth of past five years with no negative profitability and earnings

- Value Criteria 5: Price Earnings Ratio of 9.0 or less

- Value Criteria 6: Companies with Price to Book Value Ratio less than 1.20

- Value Criteria 7: Companies with constant dividend pay-out ratio

In inclination towards primary data, experts and active investors were too asked for their response for Benjamin Graham's 7 Value Stock Criterion. The experts were asked to give a pair-wise comparison for 7 criteria, based on which following weights were assigned to all factors. This framework is known as 'Priority Vector Matrix' for which following equation can be observed:

Table 3: 7 Values Investing Criterion \& Assigned Weights to Selected Companies

\begin{tabular}{|c|c|c|}
\hline 7 Value Criterion & Assigned Weights & Ranks \\
\hline Earnings Per Share Growth & 0.24 & I \\
\hline Price to Earnings Ratio & 0.21 & II \\
\hline Price to Book Value Ratio & 0.15 & III \\
\hline Current Ratio & 0.12 & IV \\
\hline Total Debt to Current Assets & 0.11 & V \\
\hline Credit Rating & 0.09 & VI \\
\hline Dividend Pay-out & 0.08 & VII \\
\hline
\end{tabular}

Final weights were derived by taking the product of assigned weights on the basis of both secondary and primary data which is shown in Table 4.

Table 4: Value Investing Criterion \& Assigned Weights by Experts/Active Investors

\begin{tabular}{|l|c|c|c|}
\hline \multicolumn{1}{|c|}{ Name of Selected Companies } & $\begin{array}{c}\text { Final } \\
\text { Weight }\end{array}$ & $\begin{array}{c}\text { Final Weight } \\
\text { in \% }\end{array}$ & Rank \\
\hline Bharti Infratel Ltd. & 0.16017 & $16.02 \%$ & I \\
\hline IOCL & 0.15861 & $15.86 \%$ & II \\
\hline Hindalco Industries Ltd. & 0.1306 & $13 \%$ & III \\
\hline Eicher Motors Ltd. & 0.11656 & $11.66 \%$ & IV \\
\hline Dr. Reddy's Laboratories Ltd. & 0.10865 & $10.87 \%$ & V \\
\hline India Bulls Housing Finance Ltd. & 0.0907 & $9.07 \%$ & VI \\
\hline
\end{tabular}

\begin{tabular}{|l|c|c|c|} 
Aurobindo Pharma Ltd. & 0.07856 & $7.86 \%$ & VII \\
\hline Adani Ports \& Special Economic & 0.07833 & $7.83 \%$ & VIII \\
\hline Indusind Bank Ltd. & 0.07782 & $7.78 \%$ & IX \\
\hline
\end{tabular}

Table 5: Final Weight Matrix

\begin{tabular}{|c|c|c|c|c|c|c|c|}
\hline $\begin{array}{l}\text { Name of Selected } \\
\text { Companies }\end{array}$ & $\begin{array}{l}\text { Cre } \\
\text { dit } \\
\text { Rat } \\
\text { ing }\end{array}$ & $\begin{array}{c}\text { To- } \\
\text { tal } \\
\text { Deb } \\
\text { t to } \\
\text { Cur } \\
\text { rent } \\
\text { As- } \\
\text { set }\end{array}$ & $\begin{array}{c}\text { Cur } \\
\text { rent } \\
\text { Ra- } \\
\text { tio }\end{array}$ & $\begin{array}{l}\text { EP } \\
\text { SG }\end{array}$ & $\begin{array}{l}\text { P/ } \\
\text { E } \\
\text { Ra } \\
\text { tio }\end{array}$ & $\begin{array}{l}\text { P/BV } \\
\text { Ratio }\end{array}$ & $\begin{array}{c}\text { Div- } \\
\text { iden } \\
\text { d } \\
\text { Pay- } \\
\text { out }\end{array}$ \\
\hline $\begin{array}{l}\text { Hindalco Indus- } \\
\text { tries Ltd. }\end{array}$ & $\begin{array}{l}0.0 \\
63 \\
\end{array}$ & $\begin{array}{c}0.22 \\
1\end{array}$ & 0.14 & $\begin{array}{l}0.0 \\
61 \\
\end{array}$ & $\begin{array}{l}0.1 \\
79 \\
\end{array}$ & 0.169 & $\begin{array}{c}0.07 \\
8\end{array}$ \\
\hline $\begin{array}{l}\text { Dr. Reddy's La- } \\
\text { boratories Ltd. }\end{array}$ & $\begin{array}{l}0.1 \\
18\end{array}$ & $\begin{array}{c}0.15 \\
4\end{array}$ & $\begin{array}{c}0.17 \\
7\end{array}$ & $\begin{array}{l}0.0 \\
61\end{array}$ & $\begin{array}{l}0.1 \\
02\end{array}$ & 0.109 & $\begin{array}{c}0.09 \\
3\end{array}$ \\
\hline $\begin{array}{l}\text { India Bulls Hous- } \\
\text { ing Finance Ltd. }\end{array}$ & $\begin{array}{l}0.1 \\
03 \\
\end{array}$ & $\begin{array}{c}0.06 \\
2\end{array}$ & $\begin{array}{c}0.07 \\
7\end{array}$ & $\begin{array}{l}0.0 \\
77 \\
\end{array}$ & $\begin{array}{l}0.0 \\
59\end{array}$ & 0.102 & 0.24 \\
\hline $\begin{array}{l}\text { Eicher Motors } \\
\text { Ltd. }\end{array}$ & $\begin{array}{l}0.0 \\
54\end{array}$ & $\begin{array}{c}0.11 \\
7\end{array}$ & $\begin{array}{c}0.10 \\
1\end{array}$ & $\begin{array}{l}0.1 \\
78\end{array}$ & $\begin{array}{l}0.1 \\
57\end{array}$ & 0.042 & $\begin{array}{c}0.05 \\
9\end{array}$ \\
\hline $\begin{array}{l}\text { Bharti Infratel } \\
\text { Ltd. }\end{array}$ & $\begin{array}{l}0.1 \\
62 \\
\end{array}$ & $\begin{array}{c}0.03 \\
6\end{array}$ & $\begin{array}{c}0.08 \\
1\end{array}$ & $\begin{array}{l}0.2 \\
23 \\
\end{array}$ & $\begin{array}{l}0.2 \\
32 \\
\end{array}$ & 0.153 & $\begin{array}{c}0.08 \\
4\end{array}$ \\
\hline IOCL & $\begin{array}{l}0.3 \\
17 \\
\end{array}$ & $\begin{array}{c}0.17 \\
6\end{array}$ & $\begin{array}{c}0.09 \\
3\end{array}$ & $\begin{array}{l}0.1 \\
88\end{array}$ & $\begin{array}{l}0.0 \\
44\end{array}$ & 0.176 & $\begin{array}{c}0.23 \\
5\end{array}$ \\
\hline $\begin{array}{l}\text { Adani Ports \& } \\
\text { Special Economic } \\
\text { Zone Ltd. }\end{array}$ & $\begin{array}{l}0.0 \\
54\end{array}$ & $\begin{array}{c}0.07 \\
1\end{array}$ & $\begin{array}{c}0.12 \\
2\end{array}$ & $\begin{array}{l}0.0 \\
52\end{array}$ & $\begin{array}{l}0.0 \\
82\end{array}$ & 0.1 & $\begin{array}{c}0.07 \\
9\end{array}$ \\
\hline $\begin{array}{l}\text { Aurobindo Phar- } \\
\text { ma Ltd. }\end{array}$ & $\begin{array}{l}0.0 \\
64 \\
\end{array}$ & $\begin{array}{c}0.09 \\
3\end{array}$ & $\begin{array}{c}0.11 \\
4\end{array}$ & $\begin{array}{c}0.0 \\
8\end{array}$ & $\begin{array}{l}0.0 \\
63 \\
\end{array}$ & 0.074 & $\begin{array}{c}0.06 \\
7\end{array}$ \\
\hline $\begin{array}{l}\text { Indusind Bank } \\
\text { Ltd. }\end{array}$ & $\begin{array}{l}0.0 \\
65\end{array}$ & 0.07 & $\begin{array}{c}0.09 \\
5\end{array}$ & $\begin{array}{c}0.0 \\
8\end{array}$ & $\begin{array}{l}0.0 \\
82\end{array}$ & 0.075 & $\begin{array}{c}0.06 \\
5\end{array}$ \\
\hline
\end{tabular}

\section{Results and Discussion}

In this research piece of paper, an attempt is made to explore the stock selection method. Primarily, fundamentals were observed with the help of the Single Index Model, CAPM, Jensen's Measure, Treynor \& Sharpe Ratio. Over and above, additionally, fuzzy Set theories were tried to fit for evaluating the proportion and ranking to the selected 9 stocks. Results states that if portfolio consists the quantum and proportion of funds as per Table 4, it would result in optimal portfolio selection based on fuzzy numbers. The research notion is thus backed with the ranking order of the stocks as well as the proportion the investor should invest in a particular stock. The selected 9 companies are from diverse indexes such as telecom, oil, metals, automobile, pharma, housing finance, infrastructure and banking. This signifies the diversification of systematic risk and to have a control over risk to some extent.

\section{References}

[1] Patni I, Gupta DK (2015), Exploring the Behavioral Biases for Equity Investment: An Empirical Study on Active Investors of Jaipur City. Asian Journal of Management 6(3), 159-62.

[2] Treynor JL. Jack Treynor's' Toward a Theory of Market Value of Risky Assets'

[3] Sharpe WF (1964), Capital asset prices: A theory of market equilibrium under conditions of risk. The journal of finance 19(3), 425-42.

[4] Lintner J (1965), Security prices, risk, and maximal gains from diversification. The journal of finance 20(4):587-615.

[5] Lintner J (1965), The valuation of risk assets and the selection of risky investments in stock portfolios and capital budgets. The review of economics and statistics 13-37.

[6] Mossin J (1966), Equilibrium in a capital asset market. Econometrica: Journal of the econometric society 768-83.f

[7] Perold AF (2004), The capital asset pricing model. The Journal of Economic Perspectives 18(3), 3-24.

[8] Braga MD (2016), The Traditional Approach to Asset Allocation. In Risk-Based Approaches to Asset Allocation, Springer International Publishing, pp. 3-15.

[9] Gregová PG (2013), CAPM \& Optimal Portfolio. The 7th International Days of Statistics and Economics, Prague. 
[10] Friend I, Blume M (1970), Measurement of portfolio performance under uncertainty. The American Economic Review 561-75.

[11] Gitman, Lawrence J (1990), Fundamentals of Investing. Boston: Pearson Education.

[12] Inuiguchi M, Ramık J (2000), Possibilistic linear programming: a brief review of fuzzy mathematical programming and a comparison with stochastic programming in portfolio selection problem. Fuzzy sets and systems 111(1), 3-28.

[13] Inuiguchi M, Tanino T (2000), Portfolio selection under independent possibilistic information. Fuzzy sets and systems 115 (1), 83-92.

[14] Tanaka H, Guo P, Türksen IB (2000), Portfolio selection based on fuzzy probabilities and possibility distributions. Fuzzy sets and systems 111(3), 387-97.

[15] Parra MA, Terol AB, Uria MR (2001), A fuzzy goal programming approach to portfolio selection. European Journal of Operational Research 133(2), 287-97.

[16] Zadeh LA (1996), Fuzzy sets. InFuzzy Sets, Fuzzy Logic, and Fuzzy Systems: Selected Papers by Lotfi A Zadeh (pp. 394-432).

[17] Smithson M (1982), Applications of fuzzy set concepts to behavioural sciences. Mathematical Social Sciences 2(3), 257-74.

[18] Graham B (1965), The intelligent investor: A book of practical counsel. Prabhat Prakashan.

[19] Tiryaki F, Ahlatcioglu B (2009), Fuzzy portfolio selection using fuzzy analytic hierarchy process. Information Sciences 179(1), 5369.

[20] Jefmański B (2014), Application of Rating Scale Model in Conversion of Rating Scales' Points To The Form Of Triangular Fuzzy Numbers. Folia Oeconomica Stetinensia 14(2), 7-18.

[21] Patni, I., Choudhary, S., \& Choubey, S. (2015). Analyzing the Robust Factors of Overconfidence Bias and its Impact: An Interpretive Structural Modeling Approach. Indian Journal of Research in Capital Markets, 2(3), 22-35. 